\title{
Shape Control of Flexible Object \\ by Multiple Wires' Constrains
}

\section{$\bigcirc$ 林 喜章 (九大) 正山本元司 (九大) 正毛利 彰 (九大)}

Yoshiaki HAYASHI, Kyushu University, 6-10-1 Hakozaki, Higashi-ku, Fukuoka Motoji YAMAMOTO, Kyushu University

Akira MOHRI, Kyushu University

Key Words : Shape Control, Flexible Object, Wire's Constraints

\section{1 はじめに}

福祉・介護用メカトロニクス機械においては人に接触しな がらの動作が必要となるため, 安全性や人との親和性が重 要となる。このため従来のような硬い動作をおこなう機械 ではなく,アクチュエータや機構全体に受動的柔らかさを持 つものが望まれる。このような受動的や柔らかさを持つ機 械の機構部・駆動部としては, バネなど弾性要素を機構部に 用いて電気モータで駆動するものや，ワイヤや形状記憶合 金で駆動することで駆動部に弾性要素を持たせるものなど がある [1][2]. この研究ではコンパクトに機構構成可能であ る利点を考え, 複数ワイヤにより柔軟物を拘束・制御し, 結 果的に受動的柔らかさを持つ機構を提案する.ここではこ の機構に多くの動作自由度を持たせるため, 複数個所で柔 軟物をワイヤ拘束し，その形状制御をおこなう。本報ではワ イヤ操作量に対する提案機構の動作解析をおこない，実験 によりその有効性を示す。

\section{2 複数ワイヤによる柔軟物拘束機構}

この研究では，柔軟物の自在な形状制御を目標とし，特 に, 柔軟物の複数注目点の形状 (位置) を操作することを目 的とする。ここでは 2 組のワイヤを腱駆動方式により拘束・ 制御することを考え，4本のワイヤで注目点の制御をおこな う.これを複数個所でおこなうことで, 柔軟物全体の形状制 御が可能となる。

なお，ワイヤを用いて 1 つの剛体の $n$ 自由度を拘束・操作 するためには, 最低 $n+1$ 本のワイヤが必要となることが知 られている.ここでは 1 つの注目点に対して 4 本のワイヤ を使用しており, 残りの 3 自由度に関して機構の弾性や重力 を利用することで受動的にその自由度が決定され，結果的 に受動的柔らかさを持つ機構になる。

図 1 に提案するワイヤによる拘束機構を示す.この研究で は柔軟物として空圧機器用ゴムホースを用いている。この ホースには一定間隔でディスクと呼ぶ部品をホースに貫通 させておりこのディスクを通してワイヤを拘束し先端部お よび途中の形状を制御する。

\section{3 変位解析}

\section{1 座瀷系の設定}

ワイヤ操作により，柔軟物であるホースの形状を制御す るため, ワイヤ操作量 $l$ に対する $x$ 軸方向 (図 1 参照) 変位 の解析をおこなう。ここでは先端部のディスクおよび途中の ディスクの 2 箇所で拘束したモデルに対して解析をおこな う.ホースの自然状態は重力下向きであるとする. 図 1 のよ うに座標系を設定し，以下で用いる主な記号をまとめる。

$$
\begin{aligned}
& N: \text { 全ディスクの枚数 } \\
& l: \text { ワィ操作量 } \\
& h: \text { ディスク間距離 } \\
& r: \text { ティスク中心とワィヤ貫通孔との距離 }
\end{aligned}
$$

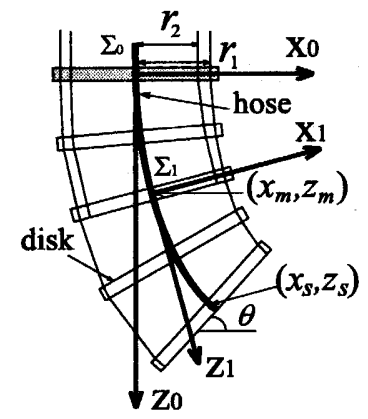

Fig.1 Coordinate systems

$m:$ 操作する途中のディスクより先のディスクの枚数 ただし $h$ は一定の值とする.ここでは 2 箇所で拘束するた め合計 8 本， 4 組のワイヤを用いることになる．このとき， 先端操作点ディスクおよびそのワイヤに関するものに添字 $1\left(l_{1}, r_{1}\right.$ など) を, 中間操作点のディスクおよびそのワイヤに 関するものに添字 $2\left(l_{2}, r_{2}\right.$ など $)$ を用いる. $l_{1}$ を $l_{1}=l_{m 1}+l_{s 1}$ とおき，

$l_{m 1}$ :途中のディスクまでを操作するときに必要な操作量 $l_{s 1}$ :途中から先の操作に必要な操作量 とする。

\section{2 途中ディスクの位置}

各ディスク間でのワイヤ操作量変化分 $\Delta l$ とディスクの傾 きの変化分 $\Delta \theta$ との間には

$$
\Delta l=r \Delta \theta
$$

の関係がある，ホースに加えられる曲げモーメントを $M_{0}$ と すると, 各ディスク間においてホースの傾きとたわみ量は梁 の曲げ理論より

$$
\begin{aligned}
& \Delta \theta=\frac{1}{E I} \int-M(z) d z=\frac{M_{0} h}{E I} \\
& \Delta x=\int \Delta \theta d z=\frac{M_{0} h^{2}}{2 E I}=\frac{\Delta \theta}{2} h
\end{aligned}
$$

となる。これらの関係より操作する途中のディスクの中心位 置, 傾き角は

$$
\begin{aligned}
{ }^{0} x_{m} & =\frac{n h}{2 r_{2}} l_{2} \\
{ }^{0} z_{m} & =(N-m) h-\frac{\left(n^{2}-1\right) h}{6 n r_{2}^{2}} l_{2}^{2} \\
\theta_{m} & =\frac{l_{2}}{r_{2}}=\frac{l_{m 1}}{r_{1}}
\end{aligned}
$$



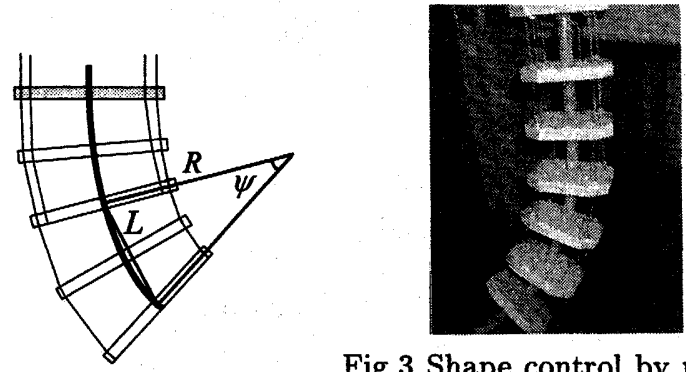

Fig.3 Shape control by multi-

Fig.2 Model of hose bending ple wires' constraints

と書くことができる $[3]$. ここでベース（ $\Sigma_{0}$ 原点）に近い数 枚のディスクは重力の影響によりほとんど動かないとし，途 中までのディスクの枚数 $(N-m)$ 枚からその枚数分だけ減 らしたものを $n$ としている. また式 $(6)$ より

$$
\begin{aligned}
& l_{m 1}=\frac{r_{1}}{r_{2}} l_{2} \\
& l_{s 1}=l_{1}-l_{m 1}=l_{1}-\frac{r_{1}}{r_{2}} l_{2}
\end{aligned}
$$

\section{3 先端ディスクの位置}

ベース座標系 $\left(\Sigma_{0}\right)$ での先端ディスクの位置を求めるため, まず座標系 $\Sigma_{1}$ での值を求める． $\Sigma_{1}$ における先端ディスク の傾き角 $\psi$ は

$$
\psi=\theta-\theta_{m}=\theta_{s}-\phi
$$

ここで $\theta_{s}$ は重力を考慮しないときのワイヤ操作量 $l_{s 1}$ によ る座標系 $\Sigma_{1}$ から見た先端ディスクの傾き角であり，

$$
\theta_{s}=\frac{l_{s 1}}{r_{1}}
$$

と書ける。またた $\phi$ は重力による影響により鉛直向きに戻る 角度を表しており，これはミオソテスの方法 [4]を用いると 次式で表される。

$$
\phi=\left\{\frac{m(m+1)(2 m+1)}{2} p+m^{3} h q\right\} \frac{g h^{2}}{6 E I} \sin \theta_{m}
$$

ここで $p, q$ はそれぞれディスク 1 枚の質量，ホースの単位長 さあたりの質量, $g$ は重力加速度である.

途中のディスクより先では $E I$ およびモーメント $M$ の変 化が小さいとして $E I, M$ を一定とみなすと, 梁の曲げ理論 より曲率 $\rho$ が一定となりホースは円軌道を描くことになる。 図 2 に示すようにこの円軌道の半径を $R$, 途中のディスクと 先端ディスクとの中心間距漏を $L$ とするとこの弧の長さは $m h$ なので半径 $R$ は

$$
R=\frac{m h}{\psi}(\psi \neq 0)
$$

ここで余弦定理より，途中ディスクと先端ディスク中心点間 距離 $L$ を求めると

$$
L= \begin{cases}\frac{2 m h}{\psi} \sin \frac{\psi}{2} & (\psi \neq 0) \\ m h & (\psi=0)\end{cases}
$$

この $L$ を用いて座標系 $\Sigma_{1}$ から見た先端ディスクの中心位置 を表すと

$$
\left\{\begin{array}{l}
{ }^{1} x_{s}=L \sin \frac{\psi}{2} \\
{ }^{1} z_{s}=L \cos \frac{\psi}{2}
\end{array}\right.
$$

式 (4)〜 (6)および式 (14) より座標系 $\Sigma_{0}$ から見た先端ディス クの中心位置, 傾き角は

$$
\begin{aligned}
& {\left[\begin{array}{l}
x \\
y \\
z
\end{array}\right]=\left[\begin{array}{c}
{ }^{0} x_{m} \\
0 \\
0 \\
{ }^{0} z_{m}
\end{array}\right]+{ }^{0} R_{1}\left[\begin{array}{c}
{ }^{1} x_{s} \\
0 \\
{ }^{1} z_{s}
\end{array}\right]} \\
& \theta=\theta_{m}+\theta_{s}-\phi
\end{aligned}
$$

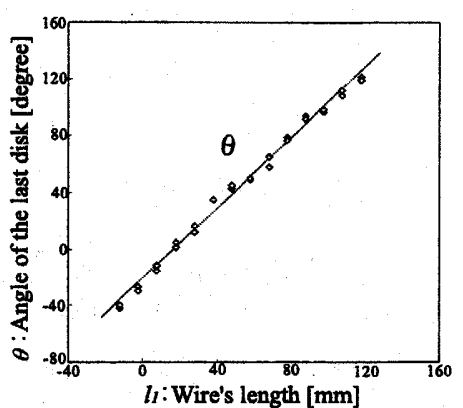

Angle of the last disk for wire's length

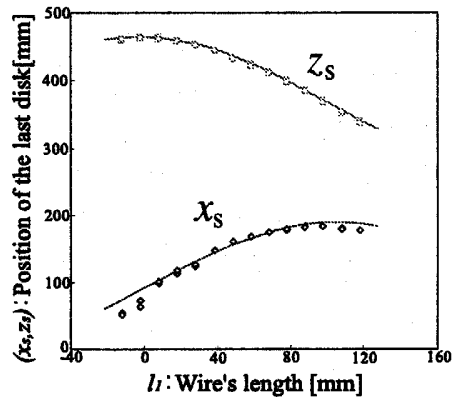

Position of the last disk for wire length

Fig.4 Experimental result

ただし, ${ }^{0} R_{1}$ は $\Sigma_{1}$ から $\Sigma_{0}$ への回転行列であり

$$
{ }^{0} R_{1}=\left[\begin{array}{ccc}
\cos \theta_{m} & 0 & \sin \theta_{m} \\
0 & 1 & 0 \\
-\sin \theta_{m} & 0 & \cos \theta_{m}
\end{array}\right]
$$

と書ける。

\section{4 動作実験}

解析結果と試作実験装置による実験結果とを比較をする。 図 3 にその装置の写真を示す.この実験では $x$ 方向に, $l_{2}$ を一定とし $l_{1}$ を操作したときの先端ディスクの中心位置と 傾き角を測定した。ワイヤにより拘束したディスクの位置は 全ディスク枚数 $N=7$ に対してベースから 5 枚目と 7 枚目 (先端部)である.このときのワイヤ操作量と先端ディスクの 傾き角との関係を図 4 上に, ワイヤ操作量と先端ディスク の中心位置との関倸を図 4 下に示す. 図に示す実験機構パ ラメータの值は $h=70[\mathrm{~mm}], r_{1}=42[\mathrm{~mm}], r_{2}=52[\mathrm{~mm}], m=2$, $l_{2}=47[\mathrm{~mm}]$. 実験では各パラメータをこの值以外の場合でも 試し，実験值と解析值がほぼ等しいことを確認した。

5 おわりに

この研究は複数箇所でのワイヤ拘束による柔軟物の形状 制御をおこなうため, ワイヤ長変化に対する機構の注目部 位に対する変位解析をおこなった。 また，実験によりその解 析の有効性を検証した。 今後はワイヤ長とワイヤ操作力の 関係を明確にし，ワイヤ拘束箇所と機構注目部の剛性（弾 性）に関する性質を調べる予定である。

\section{References}

[1] 木野，他:受動内力を利用した柔軟チューブのワイヤ駆動制御， 第 20 回日本ロボット学会学術講演会, $1 \mathrm{~F} 18,2002$

[2] 広瀬, 他:形状記憶合金アクチュエータの開発, 日本ロボット学 会誌, Vol.5, No.2, pp3-17, 1987

[3] 山本, 他:ワイヤによる柔軟ホース拘束機構の動作解析, 第 22 回日本ロボット学会学術講演会予稿集, pp.1H18, 2004

[4] 村上:材料力学, 森北出版, pp104, 1994 